\section{International Scientific Journal Theoretical \& Applied Science}

p-ISSN: $2308-4944$ (print) e-ISSN: 2409-0085 (online)

Year: 2014

Issue: 11

Published: 30.11 .2014

http://www.T-Science.org

SECTION 19. Management. Marketing. Public administration.
Irina Yurievna Belyaeva Doctor of Economic Sciences, professor, a chair of "Corporate management" department at the Financial University under the

Government of the Russian Federation, Russia tvbutova@mail.ru
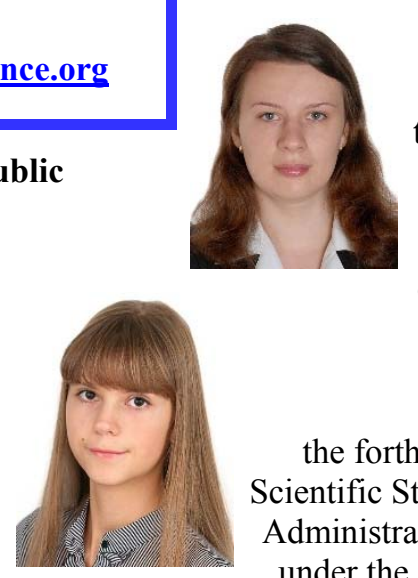

Marina Konstantinovna Krivtsova the forth-year student, the Chairman of

Scientific Student Society of Public and Municipal Administration faculty at the Financial University under the Government of the Russian Federation marinstar@bk.ru

Maria Aleksandrovna Podzorova the forth-year student, the Deputy Chairman of Scientific Student Society of Public and Municipal Administration faculty at the Financial University under the Government of the Russian Federation marusia15@inbox.ru

\title{
THE EFFICIENCY OF STANDARD REGULATION OF THE RELATIONS WITH THE STATE PARTICIPATION AS A SHAREHOLDER
}

Abstract: In this work the question of assessment of the efficiency of standard regulation of the relations with the state participation as a shareholder is considered. Within the present article the authors give concrete examples of the most typical problems of this group of corporate relations.

Key words: joint-stock company, state, corporate relations, shareholder, state representative.

Language: Russian

Citation: Belyaeva IY, Krivtsova MK, Podzorova MA (2014) THE EFFICIENCY OF STANDARD REGULATION OF THE RELATIONS WITH THE STATE PARTICIPATION AS A SHAREHOLDER. ISJ Theoretical \& Applied Science 11 (19): 7-10. doi: http://dx.doi.org/10.15863/TAS.2014.11.19.2

УДК 330

\section{ЭФФЕКТИВНОСТЬ НОРМАТИВНОГО РЕГУЛИРОВАНИЯ ОТНОШЕНИЙ С УЧАСТИЕМ ГОСУДАРСТВА В КАЧЕСТВЕ АКЦИОНЕРА}

Аннотация: В данной работе рассматривается вопрос об оченке эффективности нормативного регулирования отношений с участием государства в качестве акционера. В рамках настоящей статьи авторы приводят конкретные примеры наиболее характерных проблем этой группь корпоративных отночений.

Ключевые слова: акцุионерное общество, государство, корпоративные отношения, акциионер, представитель государства.

Статья подготовлена по результатам исследований, выполненных за счет бюджетных средств по Государственному заданию Финуниверситета 2014 года.

Отличие мотивов и интересов государства в сфере использования обычных инструментов рынка от обычных мотивов и интересов частных инвесторов, неизбежно влияет на правовой статус акционерных обществ с государственным участием, и предопределяет наличие комплекса специальных норм, регламентирующих отдельные аспекты их деятельности. Только через соотнесение заявленной цели и достигнутого результата мы можем оценить эффективность нормативного регулирования этой особой группы корпоративных отношений. 
Следует отметить отсутствие единого стержневого акта, или хотя бы специального раздела в Законе об акционерных обществах, который бы решал задачу комплексного и цельного, основанного на единых принципах правового регулирования участия Российской Федерации в акционерных обществах [1, с. 89].

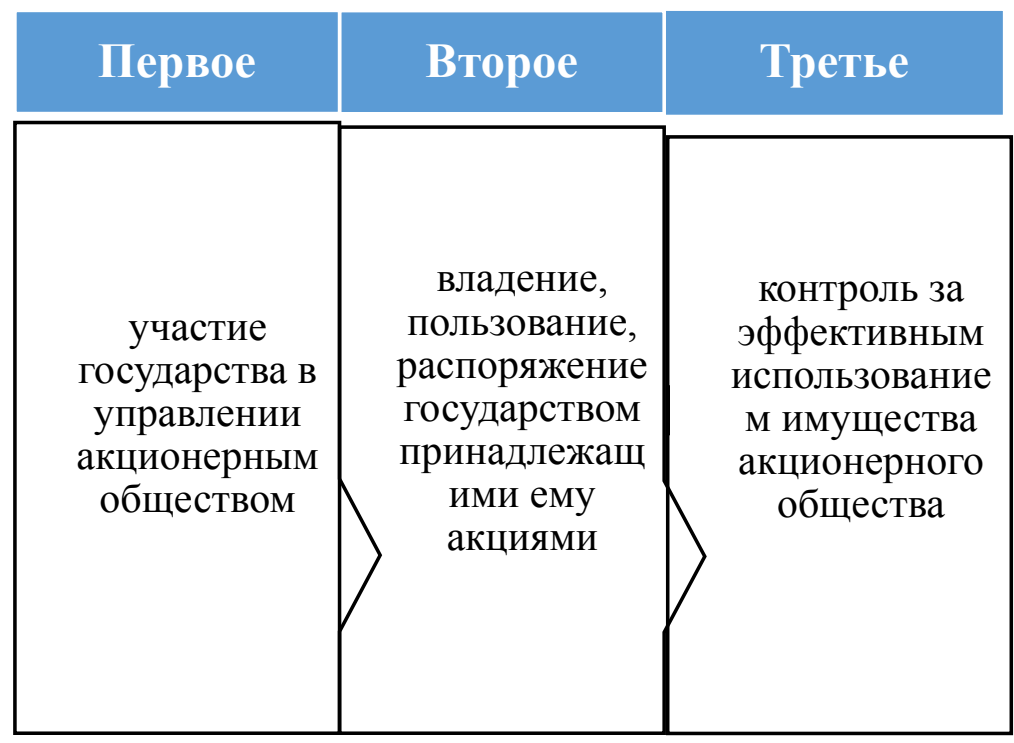

\section{Рисунок 1 - Направления правового регулирования отношений с участием государства в качестве акционера.}

Сегодня соответствующие нормы «разбросаны» по различным нормативным документам - федеральным законам (Об АО, О приватизации) и подзаконным нормативным актам (среди которых особенно следует выделить Постановление Правительства РФ от 03.12.2004 №738, Постановление Правительства РФ от 29.09.2007 № 627, Приказ Федерального агентства по управлению федеральным имуществом от 26.07.2005 № 228).

В рамках настоящего доклада мы постараемся привести отдельные примеры наиболее характерных проблем этой группы корпоративных отношений. Данные примеры, рассмотренные в совокупности, сформируют более общее представление о предмете доклада, в частности, о том, насколько удовлетворительно решена сегодня в нормативных документах задача обеспечить эффективные юридические механизмы достижения тех целей (задач), которые декларирует государство, участвуя в акционерных обществах.

1) Каждое акционерное общество, участником которого является государство, находится в ведении одного из федеральных министерств, ведомств.

Соответствующая «роспись» закреплена в подзаконных нормативных документах, определяющих правовой статус каждого из федеральных органов власти и управления.

Нередки случаи, когда отдельные акционерные общества находятся в сфере интересов одновременно нескольких федеральных органов власти и управления $[4$, с. $118]$.

Например, ОАО «Объединенная судостроительная корпорация» одновременно подчиняется Министерству промышленности и торговли (гражданское судостроение, общие вопросы), Министерству обороны (военное судостроение, судоремонт и сервисное обслуживание кораблей ВМФ) и Государственной корпорации «Росатом» (утилизация атомных подводных лодок, выведенных из состава ВМФ).

2) Как было уже отмечено при анализе нормативно-правовой базы, в основе механизма реализации государством своих полномочий как акционера лежит назначение представителей государства в органы управления акционерных обществ: Советы директоров, Наблюдательные советы, а также назначение представителей для участия в общих собраниях акционеров.

Представители государства, в свою очередь, реализуют свои полномочия посредством участия в голосовании при принятии решений. 
Постановлением Правительства РФ №738 определен перечень вопросов, по которым голосование представителей государства в органах управления осуществляется в соответствии с директивами.

Соответствующие директивы всегда оформляются только и исключительно от имени Росимущества, независимо от того, какому федеральному органу власти и управления подведомственно конкретное хозяйственное общество.

На практике это означает, что оформление директив по важнейшим управленческим решениям поручено государственному органу, не владеющему положением дел в обществе и не способному сформировать собственное отношение к сути разрешаемого вопроса. В таких условиях Росимущество, как правило, не оформляет директиву своим представителям, что блокирует принятие решений или исключает представителей государства из числа голосующих.

В итоге, государство - в лице своих представителей - не в полной мере реализует свои возможности по участию в управлении обществом, что плохо в равной мере для них обоих.

Негативные последствия такого распределения полномочий могли бы быть смягчены посредством следования Росимуществом практике оформления директив на основе заключений профильных органов власти и управления, «ответственных» за конкретное общество. Однако такая практика не сформировалась, и носит скорее исключительный характер, в силу полного отсутствия у Росимущества мотивации менять существующее положение вещей.

Другая сторона проблемы - полное самоустранение представителей государства в органах управления акционерными обществами от голосования по вопросам, в отношении которых оформление директив в соответствии с Постановлением Правительства РФ №738 не признается обязательным [3, с. 76].

3) Обращает на себя внимание тот факт, что до настоящего времени абсолютно не урегулирован в нормативных документах порядок назначения представителей государства в органы управления акционерных обществ.

В последнее десятилетие в РФ осуществлена административная реформа, внедрившая на всех уровнях управления принцип конкурсного отбора кандидатов для замещения должностей государственной службы.

Аналогичные правила установлены для муниципальной службы, судебной системы.

Вместе с тем, принципы этой реформы не оказались восприняты нормативными документами, регулирующими порядок назначения государством своих представителей в органах управления акционерными обществами с государственным участием.

Следует особо отметить в этом месте, что в отдельных акционерных обществах государство до сих пор остается единственным акционером и, таким образом, формирует $100 \%$ состава их органов управления, в т.ч. действующие на постоянной основе.

Непрозрачность системы назначения представителей государства в органах управления акционерными обществами создает благоприятные условия для злоупотреблений, снижает качество управленческих решений и эффективность реализации государством имеющихся в его распоряжении возможностей.

Этот тезис, по нашему мнению, особенно актуален для случаев назначения выдвинутых государственными органами кандидатов на оплачиваемые должности единоличных исполнительных органов, членов коллегиальных исполнительных органов акционерных обществ.

4) Представители государства на всех уровнях управления акционерными обществами не наделены какими-либо специальными полномочиями.

Вместе с тем, объективно государство как акционер имеет более широкий доступ к документам акционерных обществ, чем это определено ст.91 Закона об АО. Даже если речь не идет об обществе, в отношении которого государством принято решение об использовании «золотой акции» (абз.2 п.1 ст.91 Закона об АО), целый комплекс норм федерального законодательства, находящихся вне отрасли корпоративного права, наделяет государственные органы правами истребовать у хозяйственных обществ самую разнообразную информацию.

Таким образом, государство как участник корпоративных отношений находится в более выгодном положении, чем прочие акционеры, поскольку имеет доступ к более широкому перечню документов, сведений, и реализация этих дополнительных возможностей государства обеспечена административными, в т.ч. репрессивными, механизмами.

5) Справедливости ради необходимо отметить, что государство небезразлично к проблеме эффективности своего участия в корпоративном управлении акционерными обществами, акционером которых оно является.

Так, в 2008-м году вопрос о качестве корпоративного управления в компаниях с участием государства был поднят на встрече членов бюро правления РСПП с Президентом РФ. Представители бизнеса отметили неэффективность корпоративного управления в 
таких обществах, и изложили свое понимание причин такого положения дел.

Позиция бизнеса была поддержана Президентом РФ, в связи с чем Правительству РФ было дано поручение подготовить предложения по совершенствованию участия представителей государства в акционерных обществах [2, с. 21].

Минэкономразвития, в свою очередь, подготовило доклад, в рамках которого негативно оценило эффективность корпоративного управления в компаниях с госучастием, и предложило комплекс мер по разрешению кризисной ситуации. В качестве основной меры было предложено увеличить процент независимых директоров и профессиональных поверенных, назначаемых государством в органы управления акционерных обществ.

Предложенная концепция была поддержана Правительством РФ, были предприняты попытки реализовать ее в ходе проведения годовых общих собраний акционеров в 2009-м году. Однако первый опыт оказался неуспешным, реформа остановилась, и больше Правительство РФ к ней не возвращалось.

\section{References:}

1. Biryukov PN (2013) Mezhdunarodnoe pravo. Uchebnoe posobie. Moscow: Yurist.

2. Butova TV, Tamrazyan DA, Yadoyan VO (2013) Teoreticheskie osnovy prostranstvennoy integratsii territoriy. Upravlenie ekonomikoy regionov: funktsii i mekhanizmy upravleniya, formy i mekhanizmy vzaimodeystviya sbornik materialov Mezhdunarodnoy konferentsii. Kishinev, pp. 14-17.

3. Ganem Said Saad (2010) Pravovoy status postoyannykh predstaviteley gosudarstv pri mezhdunarodnykh organizatsiyakh universal'nogo kharaktera: Avtoreferat dissertatsii na soiskanie uchenoy stepeni kandidata yuridicheskikh nauk. Spetsial'nost' 12.00.10 - Mezhdunarodnoe pravo Nauch. ruk. V.M. Shurshalov; Universitet druzhby narodov. Moscow..

4. Glebov IN (2012) Mezhdunarodnoe pravo. Moscow: Izdatel'stvo Drofa.

5. Kuznetsov SA (2010) Predstaviteli gosudarstv v mezhdunarodnykh organizatsiyakh. Moscow. Pravo.
6. Lukashuk II (2011) Mezhdunarodnoe pravo: osobennaya chast': uchebnik dlya studentov yuridicheskikh fakul'tetov i vuzov. - Izd. 3-e, pererab. i dop. - Moscow: Volters Kluver.

7. Pukhova MM (2013) Problemy korporativnogo stroitel'stva v sovremennoy Rossii// Ekonomicheskie sistemy. No. 2. pp. 37-44.

8. Ragulina YV (2011) O konkurentosposobnosti otechestvennoy ekonomiki. Nauchnoe obozrenie. No. 5. pp. 486-491.

9. Chistokhodova IA (2010) Mezhdunarodnopravovoy status i funktsii zarubezhnykh predstavitel'stv gosudarstv i mezhdunarodnykh mezhpravitel'stvennykh organizatsiy: Avtoreferat dissertatsii na soiskanie uchenoy stepeni kandidata yuridicheskikh nauk. Spetsial'nost': 12.00 .10 - Mezhdunarodnoe pravo; Evropeyskoe pravo; Nauch. ruk. A. Kh. Abashidze. - Moscow.

10. Official Records of the Economic and Social Council, Forty-fiiith session, Suppl. No 3; Doc. 1/4491, pp. $114-115$. 